\title{
Novel polymorphisms detected in the prolactin receptor gene of Yili horse (Equus caballus) by PCR-SSCP
}

\author{
R. Abula ${ }^{1,2}$, H.-L. Zhang ${ }^{1}$, Y. Chen ${ }^{1,3}$, and X.-K. Yao ${ }^{1}$ \\ ${ }^{1}$ Xinjiang Key Laboratory of Meat- and Milk-Production, Herbivore Nutrition, College of Animal Science, Xinjiang Agricultural \\ University Urumqi 830052 , P. R. China \\ ${ }^{2}$ Chemical and Environmental Science Department, Kashgar Teacher's College Kashgar 844006, P. R. China
}

KEY WORDS: horse, prolactin receptor gene, polymorphism, PCR-SSCP

Received 19 September 2012

Revised 18 February 2013

Accepted 18 March 2013

${ }^{3}$ Corresponding author: e-mxjaucy@yahoo.com.cn

\begin{abstract}
The prolactin receptor (PRLR) is a receptor for a polypeptide hormone that stimulates mammary gland development and lactation in mammals. Associations between the PRLR genotype and cow and goat milk traits have been reported. To date, the nucleotide polymorphisms within the PRLR gene in equine species have not been investigated. Single-nucleotide polymorphism (SNP) is the most abundant form of genetic variation and a resource for useful genetic traits. In the present study, SNPs within the coding regions of the PRLR gene were detected by polymerase chain reaction-single-strand conformation polymorphism (SSCP) and DNA sequencing on the Yili horse of China. Ten novel SNPs were identified in the PRLR gene: one located within exon 4 (XM_001500104: c.156 $\mathrm{C}>\mathrm{T}$ ); one within exon 5 (c.312 T>C); and eight within exon 10 (c.1062 T>C, c.1083 G>A, c.1226 A>C, c.1233 C>T, c.1279 C>A, c.1749 A>T, c.1764 G>C, and $c .1778 \mathrm{~T}>\mathrm{A}$ ). The mutation allele frequencies and effective allele numbers ranged from 0.10 to 0.30 and from 1.2195 to 1.7240 , respectively. Four of the identified SNPs are non-synonymous and involve four amino acid substitutions, namely, p.H409P (c.1226 A>C), p.H427N (c.1279 C>A), p.Q588H (c.1764 G>C), and p.I593K (c.1778 T>A), in the cytoplasmic domain of the PRLR, which plays a fundamental role in signal transduction. Theoretically, the four nucleotide substitutions would result in altered spatial structure and functions of the PRLR molecules. Further study is required, however, to determine whether these mutations affect the milk yield of the Yili horse.
\end{abstract}

\section{Introduction}

China is a traditional country in terms of horserearing. In 2010, horse inventories recorded 6.787 million horses, accounting for $11.60 \%$ ofthe world's total horse population, which is second only to the United States (9.5 million) (Yao, 2011). Horses had been primarily used for labor, but have also become a major source of unique animal products, such as horsemeat and mare's milk, which are helpful in dealing with poverty.
Cow's milk or milk products are used traditionally as substitutes for human milk in infant nutrition. Cow's milk is, however, considerably different from human milk in terms of its nutrient concentrations and absorption rates, which can pose problems in infants. Equine milk is considered to be an excellent milk source for humans. Compared with cow's milk, equine milk contains less fat, protein, and inorganic salts, but more lactose, with a concentration close to that in human milk (Barello et al., 2008; Uniacke-Lowe et al., 2010). Thus, mare's milk is 
more suitable for human nourishment than cow's milk (Malacarne et al., 2002).

Many candidate genes, such as prolactin (PRL) (Lü et al., 2010), prolactin receptor (PRLR) (Zhang et al., 2008), growth hormone (Mullen et al., 2010), insulin-like growth factor 1 (Mullen et al., 2011), and insulin-like growth factor 2 (Berkowicz et al., 2011) have been associated with dairy performance traits of cattle. Among these candidates, the PRLR gene is the most important one because of its crucial role in transmitting signals from lactogenic hormones to milk protein gene promoters (Brym et al., 2005). The PRLR belongs to the same family as growth hormone receptor (GHR), which is part of the class 1 cytokine receptor superfamily (Bole-Feysot et al., 1998). PRLR has a major role in mediating of PRL action in the mammary gland, and thus the PRLR gene is considered to be responsible for milk yield (Zhang et al., 2008). A recent study has revealed that five nucleotide variations (AJ966356: g.1218 T $>$ A, g.1219 T>A, g.1220 T>G, g.1267 A > G, and g. 1268 $\mathrm{C}>\mathrm{T}$ ) in the exon 3 coding region of the PRLR gene were found and that the polymorphism was linked with milk production traits in dairy cattle (Zhang et al., 2008). A single nucleotide polymorphism (SNP) (JX087440: c.1658 T>A) in the exon 10 coding region of the PRLR gene was identified in the Saanen dairy goat, and this mutation resulted in a decrease in milk yield (Sun et al., 2008). Polymorphisms within the equine PRLR gene are still unknown, however.

The current study was designed to detect SNPs of the PRLR gene of Yili horse (a local Chinese breed) to identify potential genetic markers for lactation performance of horses. The SNPs in the eight exons of the PRLR gene were screened using polymerase-chain reaction-single strand conformation polymorphism (PCR-SSCP) and DNA sequencing methods.

\section{Material and methods}

\section{Sample collection}

Blood samples of fifty female individuals (aged 4 to 5 years) without genetic relationships were collected from the Zhaosu equine farm, Yili County, Xinjiang Uygur Autonomous Region, China. The blood samples were drawn from the jugular vein into heparin-containing vacuum blood collection tubes. The samples were stored at $-20^{\circ} \mathrm{C}$ until DNA extraction.

\section{Genomic DNA used in DNA extraction}

PCR amplification was isolated from the blood samples according to the method described by Sambrook and Russell (2001) and diluted to an optimum concentration $\left(100 \mathrm{ng} \cdot \mu \mathrm{l}^{-1}\right)$.

\section{Primer design}

Twelve pairs of specific PCR primers for the PRLR gene were designed using the Oligo 6.0 software package according to the whole genome shotgun sequence of Equus caballus chromosome 21 (Accession No: NW_001867391) and the mRNA sequence of the E. caballus PRLR gene (Accession No: XM_001500104). Eight exons (exon 3 to exon 10), a coding region for the mature PRLR protein, were included. The primer sequences are shown in Table 1. All primers were synthesized by Invitrogen Life Technologies (Shanghai, China).

\section{PCR amplification}

PCR reactions were conducted in a total volume of $20 \mu \mathrm{l}$ with $100 \mathrm{ng}$ DNA solution, $2 \mu \mathrm{l} 10 \times \mathrm{PCR}$ buffer, $0.2 \mu \mathrm{M}$ each dNTP, 4 pmol of each primer, and $2.5 \mathrm{IU}$ Taq DNA polymerase $\left(5 \mathrm{U} \cdot \mu^{-1}\right.$, TaKaRa, Dalian, China). Nuclease-free water was added to the final volume. The PCR protocol was: $94^{\circ} \mathrm{C}$ for $5 \mathrm{~min} ; 35 \times\left(94^{\circ} \mathrm{C}\right.$ for $45 \mathrm{~s}, 57^{\circ} \mathrm{C}$ to $65^{\circ} \mathrm{C}$ (depending on the primers used, see Table 1) for $30 \mathrm{~s}, 72^{\circ} \mathrm{C}$ for $\left.40 \mathrm{~s}\right), 72^{\circ} \mathrm{C}$ for $5 \mathrm{~min}$. Theamplifications were run by a thermocycler (Mycycler, BioRad, San Diego, CA, USA).

\section{SSCP analysis}

The SSCP method was used to genotype in the amplified region (Oto et al. 1993). In general, $5 \mu \mathrm{l}$ of PCR products were mixed with $10 \mu \mathrm{l}$ denaturating solution A $(0.05 \%$ xylene-cyanol, $0.05 \%$ bromophenol blue, $2 \%$ glycerol, and $0.02 \mathrm{M}$ EDTA in deionized formamide) or solution B $(0.01 \%$ xylene-cyanol, $0.01 \%$ bromophenol blue, and $10 \%$ sucrose; nuclease-free water was added to achieve the final volume of $10 \mathrm{ml}$ ) (Maruya et al., 1996). After heat denaturation at $95^{\circ} \mathrm{C}$ for $10 \mathrm{~min}$, the samples were immediately chilled on ice, and then placed at $-20^{\circ} \mathrm{C}$ for $20 \mathrm{~min}$. Polyacrylamide gel electrophoresis was initiated by pre-running for $10 \mathrm{~min}$ at a voltage of $250 \mathrm{~V}$. Subsequently, the samples were loaded and run at a fixed voltage of $130 \mathrm{~V}$ to $180 \mathrm{~V}$ for $14 \mathrm{~h}$ to $24 \mathrm{~h}$ at $4^{\circ} \mathrm{C}$ to $25^{\circ} \mathrm{C}$ in $0.5 \times$ Tris-borate-EDTA (TBE) buffer. Bands were 
Table 1. Sequences of primers and information of equine PRLR gene

\begin{tabular}{|c|c|c|c|c|}
\hline Primers & Primer sequence (5'-3') & $\begin{array}{l}\text { Fragment length, } \\
\text { bp }\end{array}$ & $\begin{array}{l}\text { Tm, } \\
{ }^{\circ} \mathrm{C}\end{array}$ & Amplicons $^{1}$ \\
\hline P1 & $\begin{array}{l}\text { F: GCCTGATGCCTTCTTTTTTCAGT } \\
\text { R: GTGATGGACTCTCCACCCTCTT }\end{array}$ & 204 & 64 & $\begin{array}{l}\text { exon 3: } \\
\text { g. } 25992507-25992710\end{array}$ \\
\hline P2 & $\begin{array}{l}\text { F: GCACCTTAATATTGACTCCAG } \\
\text { R: GAGTGAGAACACTCTTGTGAAG }\end{array}$ & 225 & 57 & $\begin{array}{l}\text { exon 4: } \\
\text { g. } 25995225-25995449\end{array}$ \\
\hline P3 & $\begin{array}{l}\text { F: GCCATAGTATATTACCCGTTGC } \\
\text { R: GAGTAACAAACTCCTCACCTACC }\end{array}$ & 229 & 60 & $\begin{array}{l}\text { exon 5: } \\
\text { g. } 25996792-25997018\end{array}$ \\
\hline P4 & $\begin{array}{l}\text { F: TGGAGTTTCTTTCACATCTGC } \\
\text { R: CAAAAGCTTCTAGTTGACTCACC }\end{array}$ & 215 & 59 & $\begin{array}{l}\text { exon 6: } \\
\text { g.26000487-26000701 }\end{array}$ \\
\hline P5 & $\begin{array}{l}\text { F: ACTTCTGTCTTCCTTGTTCCTC } \\
\text { R: CAAAAGGTAGCTGAGACACTCAC }\end{array}$ & 192 & 61 & $\begin{array}{l}\text { exon } 7 \text { : } \\
\text { g.26002030-26002221 }\end{array}$ \\
\hline P6 & $\begin{array}{l}\text { F: GTATGCGATTAAAGCTTTCTGG } \\
\text { R: ATGAATATTGGGGGAGGGTT }\end{array}$ & 175 & 62 & $\begin{array}{l}\text { exon 8: } \\
\text { g.26003432-26003606 }\end{array}$ \\
\hline P7 & $\begin{array}{l}\text { F: AAAGTGAGAAGATGAGCCAT } \\
\text { R: AGTGAGTCATACTACATTCTCCAC }\end{array}$ & 155 & 62 & $\begin{array}{l}\text { exon 9: } \\
\text { g.26004041-26004195 }\end{array}$ \\
\hline P8 & $\begin{array}{l}\text { F: CAGCCATCTCTCCTTGTGTCT } \\
\text { R: CAGAGTCACTGTCAGGATCCA }\end{array}$ & 226 & 65 & $\begin{array}{l}\text { partial exon 10: } \\
\text { g.26005932-26006157 }\end{array}$ \\
\hline P9 & $\begin{array}{l}\text { F: AAAGGTATGAAGCCCACCCAC } \\
\text { R: GGCAAAGGCCATGTTGAAGAT }\end{array}$ & 257 & 65 & $\begin{array}{l}\text { partial exon10: } \\
\text { g.26006118-26006372 }\end{array}$ \\
\hline P10 & $\begin{array}{l}\text { F: TATTTCCACGTCGACGGATC } \\
\text { R: CCATGCTCTGTCTTGGTCAGT }\end{array}$ & 267 & 64 & $\begin{array}{l}\text { partial exon10: } \\
\text { g.26006328-26006594 }\end{array}$ \\
\hline P11 & $\begin{array}{l}\text { F: CGAGCAGAGAGAGGTGGAAAG } \\
\text { R: GATGTTGTTATCCGTCACCTGG }\end{array}$ & 248 & 66 & $\begin{array}{l}\text { partial exon10: } \\
\text { g.26006540-26006787 }\end{array}$ \\
\hline P12 & F: TACGCTAAGGTGTCCCAGGT & & & partial exon10: \\
\hline & R: AGCTGTCACTGAAAGGAGTGC & 239 & 65 & g.26006754-26006992 \\
\hline
\end{tabular}

${ }^{1}$ based on the whole genome shotgun sequence of Equus caballus chromosome 21 (Accession No: NW_001867391); $\mathrm{F}$ - forward primer, $\mathrm{R}$ - reverse primer

Table 2. SSCP electrophoresis conditions for equine PRLR gene

\begin{tabular}{|c|c|c|c|c|c|c|}
\hline Primers & $\begin{array}{l}\text { Gel concentration } \\
\%\end{array}$ & $\begin{array}{l}\text { Glycerol in gel } \\
\%\end{array}$ & $\begin{array}{l}\text { Denaturating } \\
\text { solution }\end{array}$ & $\begin{array}{l}\text { Running } \\
\text { temperature } \\
{ }^{\circ} \mathrm{C}\end{array}$ & $\begin{array}{l}\text { Running } \\
\text { time } \\
\mathrm{h}\end{array}$ & $\begin{array}{l}\text { Running } \\
\text { voltage } \\
\text { V }\end{array}$ \\
\hline$\overline{P 1}$ & 10 & - & $B$ & 10 & 15 & 150 \\
\hline P2 & 10 & - & $A$ & 12 & 16 & 150 \\
\hline P3 & 12 & - & $A$ & 25 & 14 & 150 \\
\hline P4 & 10 & 0.5 & $A$ & 25 & 14 & 150 \\
\hline P5 & 12 & - & $A$ & 25 & 14 & 150 \\
\hline P6 & 10 & - & B & 10 & 16 & 150 \\
\hline P7 & 12 & 0.5 & $A$ & 8 & 18 & 130 \\
\hline P8 & 12 & - & B & 10 & 16 & 150 \\
\hline P9 & 12 & - & B & 8 & 18 & 150 \\
\hline P10 & 12 & - & $B$ & 4 & 24 & 180 \\
\hline P11 & 12 & - & B & 10 & 16 & 150 \\
\hline P12 & 12 & - & $\mathrm{B}$ & 12 & 16 & 150 \\
\hline
\end{tabular}

visualized by silver staining (Bassam et al., 1991). Detailed SSCP electrophoresis conditions are listed in Table 2.

\section{DNA sequencing}

The DNA samples that showed different patterns on the SSCP gels were selected for sequencing. The PCR products were purified with an agarose gel extraction kit (Tiangen
Biotech, Beijing, China) and then sequenced by an ABI PRISM 377 automated sequencer (Perkin Elmer-Applied Biosystems Division, USA) from Invitrogen Life Technologies (Shanghai, China) using the respective primers described above. These nucleotide sequences were compared with the mRNA sequence of the E. caballus PRLR gene (Accession No: XM_001500104). Mutations were defined using BioEdit software (Hall, 1999). 


\section{Data analysis}

Genotypic and allelic frequencies were calculated, and the Hardy-Weinberg equilibriums were detected by the PopGen32 software package. The distribution of these genotypes was analyzed using the $\chi^{2}$-test, performed using PASW Statistics 18.0. Population genetic indices, such as $\mathrm{He}$ (gene heterozygosity), Ho (gene homozygosity), Ne (effective allele numbers), and PIC (polymorphism information content), were calculated according to a previous report (Han et al., 2011).

\section{Results}

Polymorphisms of the PRLR gene were screened by PCR-SSCP. No polymorphism was detected within exons $3,6,7,8$, or 9. Only the PCR products amplified by primers $\mathrm{P} 2, \mathrm{P} 3, \mathrm{P} 9, \mathrm{P} 10$, and P12 displayed polymorphisms.

\section{SNP within exon 4 of the PRLR gene}

Two patterns were identified within exon 4 of the PRLR gene in the Yili horse by PCR-SSCP (Figure 1). The single-strand DNA patterns in lanes $1,2,5,6,7$, and 8 were different from those in lanes 3 and 4. DNA sequence analysis, according to the reference sequence of GenBank accession no. XM_001500104, revealed a c.156 C > T transition. The more common pattern corresponded to the known sequence. The frequency of allele $\mathrm{T}$ was 0.17 (Table 3). The $\chi^{2}$-test showed that distribution of genotypes in the Yili breed was consistent with the Hardy-Weinberg equilibrium $(\mathrm{P}>0.05) .1 \mathrm{On}$ this locus, genetic indices such as $\mathrm{Ho}, \mathrm{He}, \mathrm{Ne}$, and PIC were 0.7048, 0.2952, 1.4188, and 0.2516, respectively (Table 4). This mutation was a synonymous one (Table 5).

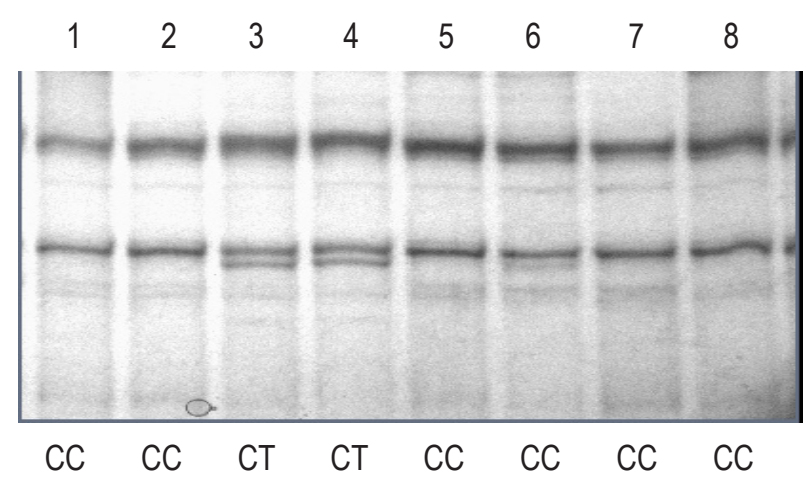

Figure 1. Single-strand DNA pattern on $10 \%$ polyacrylamide gel after denaturing of the PCR fragments containing c. $156 \mathrm{C}>\mathrm{T}$ mutation of the equine PRLR exon 4. T and $C$ are the wild-type and mutant alleles, respectively. Lanes 1, 2, and 5 to 8 are the CC genotypes (wild-type); lanes 3 and 4 are the CT genotypes (heterozygote)
Table 3. Frequencies of alleles and genotypes at the five loci in $P R L R$ gene of Yili horse

\begin{tabular}{|c|c|c|c|c|c|c|c|c|}
\hline \multirow{2}{*}{$\begin{array}{l}\text { Loci } \\
\text { c.156 C>T }\end{array}$} & \multirow{2}{*}{$\begin{array}{l}\mathrm{N} \\
50\end{array}$} & \multicolumn{2}{|c|}{$\begin{array}{l}\text { Genotypic } \\
\text { frequency }\end{array}$} & \multirow[b]{2}{*}{$\mathrm{TT}$} & \multicolumn{2}{|c|}{$\begin{array}{l}\text { Allele } \\
\text { frequency }\end{array}$} & \multicolumn{2}{|c|}{$X^{2}\left(H_{W E}{ }^{1}\right) P$-value } \\
\hline & & CC & CT & & $C$ & $\mathrm{~T}$ & & \\
\hline & & $\begin{array}{l}0.66 \\
(33)^{2}\end{array}$ & $\begin{array}{l}0.34 \\
(17)\end{array}$ & $0(0)$ & 0.83 & 0.17 & 0.3530 & 0.552 \\
\hline \multirow[t]{2}{*}{ c. $312 \mathrm{~T}>\mathrm{C}$} & 50 & $\mathrm{TT}$ & $\mathrm{TC}$ & CC & $\mathrm{T}$ & C & & \\
\hline & & $\begin{array}{l}0.54 \\
(27)\end{array}$ & $\begin{array}{l}0.32 \\
(16)\end{array}$ & $0.14(7)$ & 0.70 & 0.30 & 2.8340 & 0.092 \\
\hline
\end{tabular}

C. $1062 \mathrm{~T}>\mathrm{C}$

c.1083 G>A 50 TT/GG/ TC/GA/ CC/AA/ T/G/ C/A/

c.1226 A $>C$ AA/CC AC/CT CC/TT A/C C/T

c. $1233 \mathrm{C}>\mathrm{T}$

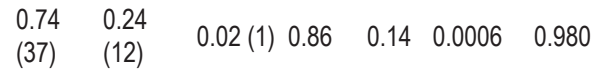

c.1279C $>$ A 50 CC CA AA C $A$

$0.72 \quad 0.24$

(36) (12)

$0.04(2) \quad 0.84 \quad 0.16 \quad 0.5740 \quad 0.449$

c. $1749 \mathrm{~A}>\mathrm{T}$

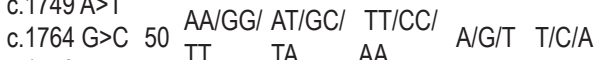

c. $1778 \mathrm{~T}>\mathrm{A}$

$0.80 \quad 0.20$

(40) (10)

$0(0) \quad 0.90 \quad 0.10 \quad 0.6173 \quad 0.4321$

${ }^{1}$ Hardy-Weinberg equilibriums; ${ }^{2}$ data in bracket are the numbers of observation

Table 4. Genetic indices at the five loci in PRLR gene of Yili horse

\begin{tabular}{|c|c|c|c|c|}
\hline Loci & $\mathrm{Ho}^{1}$ & $\mathrm{He}^{2}$ & $\mathrm{Ne}^{3}$ & $\mathrm{PIC}^{4}$ \\
\hline c. 156 C>T & 0.7048 & 0.2952 & 1.4188 & 0.2516 \\
\hline c. $312 \mathrm{~T}>\mathrm{C}$ & 0.5800 & 0.4200 & 1.7240 & 0.3318 \\
\hline $\begin{array}{l}\text { c. } 1062 \mathrm{~T}>\mathrm{C} \\
\text { c. } 1083 \mathrm{G}>\mathrm{A} \\
\text { c. } 1226 \mathrm{~A}>\mathrm{C} \\
\text { c. } 1233 \mathrm{C}>\mathrm{T}\end{array}$ & 0.7592 & 0.2408 & 1.3172 & 0.2118 \\
\hline c. $1279 \mathrm{C}>\mathrm{A}$ & 0.7312 & 0.2688 & 1.3676 & 0.2327 \\
\hline $\begin{array}{l}\text { c. } 1749 \text { A }>T \\
\text { c. } 1764 \mathrm{G}>\mathrm{C} \\
\text { c. } 1778 \mathrm{~T}>\mathrm{A}\end{array}$ & 0.8200 & 0.1800 & 1.2195 & 0.1638 \\
\hline
\end{tabular}

${ }^{1}$ gene homozygosity; ${ }^{2}$ gene heterozygosity; ${ }^{3}$ effective allele numbers; ${ }^{4}$ polymorphism information content

\section{SNP within exon 5 of the PRLR gene}

Three genotypes were detected within exon 5 of the PRLR gene in the Yili breed by PCR-SSCP (Figure 2). Single-strand DNA patterns of lanes 1, 2, $3,4,6$, and 8 belonged to a homozygotic genotype and that of lane 5 belonged to another homozygotic one. Lane 7 was a heterozygote. A c.312 T>C transition, corresponding to the sequence of GenBank accession no. XM_001500104, was found within exon 5 of the $P R L \bar{R}$ gene. The frequency of allele $\mathrm{C}$ was 0.30 in the breed (Table 3). The $\chi^{2}-$ test showed that the distribution of genotypes was consistent with the Hardy-Weinberg equilibrium $(\mathrm{p}>0.05)$. The Ho, He, Ne, and PIC were 0.5800 , $0.4200,1.7240$, and 0.3318 , respectively (Table 4). This mutation was silent (Table 5). 


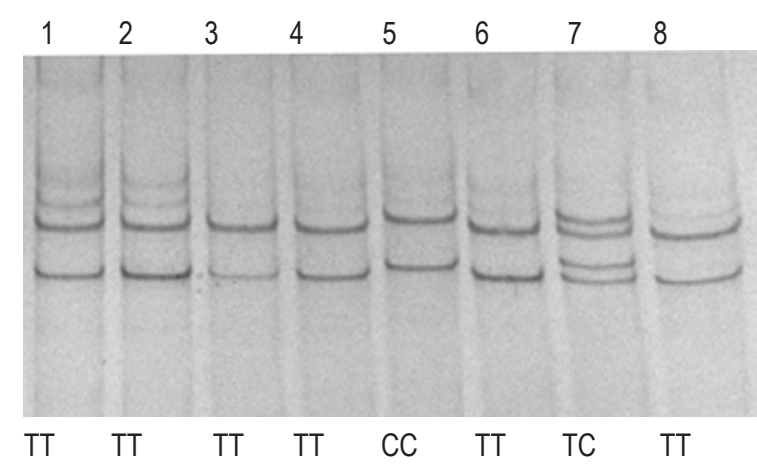

Figure 2. Single-strand DNA pattern on $12 \%$ polyacrylamide gel after denaturing of the PCR fragments containing c.312 $\mathrm{T}>\mathrm{C}$ mutation of the equine PRLR exon 5 . $\mathrm{T}$ and $\mathrm{C}$ are the wildtype and mutant alleles, respectively. Lanes 1 to 4,6 , and 8 are the TT genotypes (wild-type); lane 5 is the CC genotype (homozygous mutant); lane 7 is the TC genotype (heterozygote)

\section{SNPs within exon 10 of the PRLR gene}

Three genotypes were detected for primer P9 by the PCR-SSCP method (Figure 3). The allele that showed a sequence similar to the known sequence (GenBank accession no. XM_001500104) was labeled as $B$, whereas the new pattern was denominated as $D$. The genotype displayed on lanes $1,2,3$, and 5 were named BB; that on lane 4 was named $\mathrm{BD}$; and that on lane 6 was named DD. The result of DNA sequences alignment showed that four nucleotide variations (i.e., c.1062 T>C, c.1083 $\mathrm{G}>\mathrm{A}, \mathrm{c} .1226 \mathrm{~A}>\mathrm{C}$, and c.1233 C $>\mathrm{T}$ ) were identified on allele $\mathrm{D}$ (Table 5). The frequency of allele $\mathrm{D}$ was 0.14 in the Yili horse (Table 3). The $\chi^{2}$-test showed that the distribution of genotypes was consistent with the Hardy-Weinberg equilibrium $(\mathrm{P}>0.05)$. The $\mathrm{Ho}, \mathrm{He}, \mathrm{Ne}$, and PIC were $0.7592,0.2408,1.3172$, and 0.2118 , respectively (Table 4). Among the four variations, c.1062 $\mathrm{T}>\mathrm{C}$, c.1083 $\mathrm{G}>\mathrm{A}$, and c.1233 $\mathrm{C}>\mathrm{T}$ were synonymous. The c.1226 $\mathrm{A}>\mathrm{C}$ mutation resulted in the 409th amino acid, histidine $(\mathrm{H})$, being replaced by proline (P) (p.H409P) (Table 5).

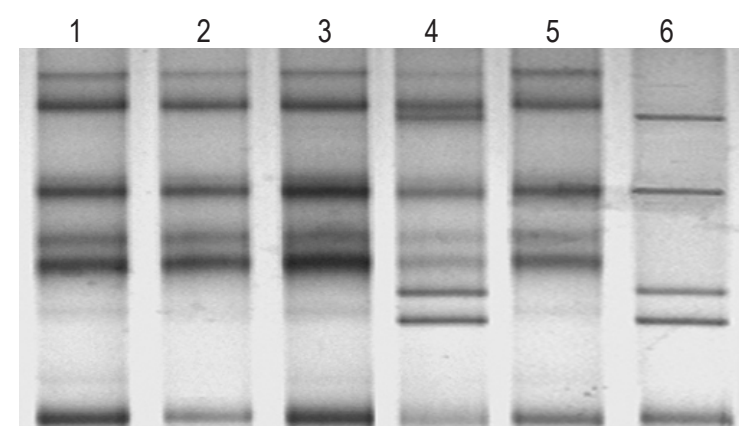

Figure 3. Single-strand DNA pattern on $12 \%$ polyacrylamide gel after denaturing of the PCR fragments amplified by primer P9. Lanes 1 to 3 , and 5 are the wild-type homozygote; lane 6 is mutant homozygote; lane 4 is the heterozygote

The single-strand DNA pattern revealed three genotypes after denaturing of the PCR fragments amplified by primer P10 (Figure 4). A transition of c.1279 C $>\mathrm{A}$, based on the referring sequence of XM_001500104, was found after DNA sequence analysis. The frequency of the mutation allele, A, was 0.16 (Table 3 ). The $\chi^{2}$-test showed that the genotypic distribution was consistent with the Hardy-Weinberg equilibrium $(\mathrm{P}>0.05)$. The Ho

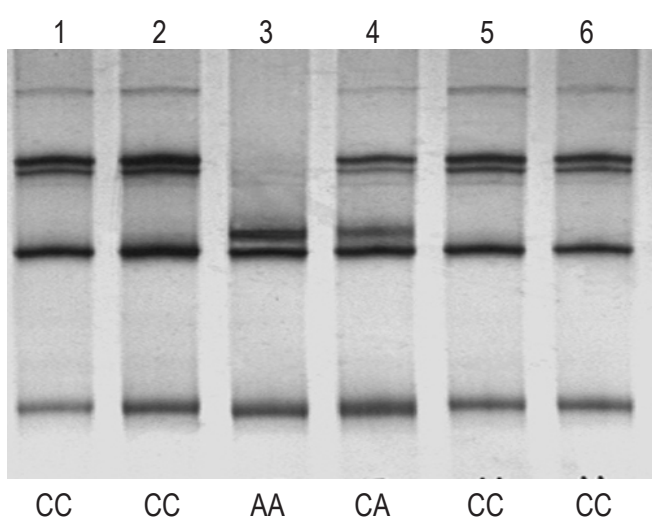

Figure 4. Single-strand DNA pattern on $12 \%$ polyacrylamide gel after denaturing of the PCR fragments amplified by primer P10. $C$ and $A$ are the wild-type and mutant alleles, respectively. Lanes 1, 2, 5, and 6 are the CC genotype (wild-type); lane 3 is the AA genotype (homozygous mutant); lane 4 is the CA genotype (heterozygote)

Table 5. SNPs identified in PRLR gene of Yili horse

\begin{tabular}{|c|c|c|c|c|c|}
\hline Loci & Position $^{1}$ & SNP & Codon change & Region & Amino acid change \\
\hline c.156 C>T & 156 & $\mathrm{C} / \mathrm{T}$ & GCC/GCT & Exon 4 & synonymous \\
\hline c. $312 \mathrm{~T}>\mathrm{C}$ & 312 & $\mathrm{~T} / \mathrm{C}$ & AAT/AAC & Exon 5 & synonymous \\
\hline c. $1062 \mathrm{~T}>\mathrm{C}$ & 1062 & $\mathrm{~T} / \mathrm{C}$ & TGT/TGC & Exon 10 & synonymous \\
\hline c. $1083 \mathrm{G}>\mathrm{A}$ & 1083 & $\mathrm{G} / \mathrm{A}$ & TCG/TCA & Exon 10 & synonymous \\
\hline c. 1226 A >C & 1226 & $\mathrm{~A} / \mathrm{C}$ & $\mathrm{CAC/CCC}$ & Exon 10 & $\mathrm{H} 409 \mathrm{P}$ \\
\hline c. 1233 C>T & 1233 & $\mathrm{C} / \mathrm{T}$ & GAC/GAT & Exon 10 & synonymous \\
\hline c. $1279 C>A$ & 1279 & $\mathrm{C} / \mathrm{A}$ & CACIAAC & Exon 10 & $\mathrm{H} 427 \mathrm{~N}$ \\
\hline c. $1749 A>T$ & 1749 & $\mathrm{~A} / \mathrm{T}$ & ССA/CCT & Exon 10 & synonymous \\
\hline c. $1764 \mathrm{G}>\mathrm{C}$ & 1764 & $\mathrm{G} / \mathrm{C}$ & CAG/CAC & Exon 10 & Q588H \\
\hline c.1778 T>A & 1778 & T/A & ATA/AAA & Exon 10 & I593K \\
\hline
\end{tabular}

${ }^{1}$ based on the mRNA sequence of $E$. caballus PRLR gene (Accession No: XM_001500104) 
$\mathrm{He}, \mathrm{Ne}$, and PIC were $0.7312,0.2688,1.3676$, and 0.2327 , respectively (Table 4). DNA sequence analysis showed that the mutation resulted in the 427th amino acid, histidine, being replaced by asparagine (N) (p.H427N) (Table 5).

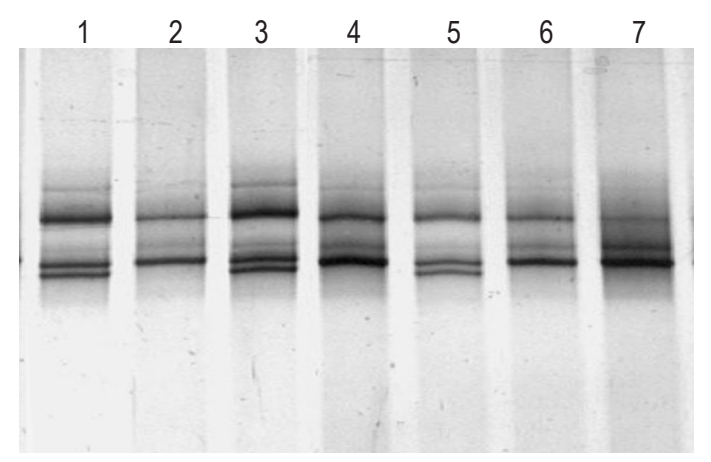

Figure 5. Single-strand DNA pattern on $12 \%$ polyacrylamide gel after denaturing of the PCR fragments amplified by primer P12. Lanes 2 , 4,6 , and 7 are the wild-type homozygote; lane 1,3 , and 5 are the heterozygote

Two patterns were detected for primer P12 (Figure 5). Compared with XM_001500104, three nucleotide variations were detected at this locus, namely c.1749 A>T, c.1764 G>C, and c.1778 $\mathrm{T}>\mathrm{A}$. The allele that showed the same sequence as the reference sequence was named $E$, whereas the new pattern was denominated as $F$. The frequency of the mutation allele, $\mathrm{F}$, was 0.10 (Table 3 ). The $\chi^{2}$-test showed that the genotypic distribution of the Yili horse was consistent with the HardyWeinberg equilibrium $(\mathrm{P}>0.05)$. The $\mathrm{Ho}, \mathrm{He}, \mathrm{Ne}$, and PIC were $0.8200,0.1800,1.2195$, and 0.1638 , respectively (Table 4). The c.1749 $\mathrm{A}>\mathrm{T}$ transition was a synonymous mutation. The c.1764 G>C transversion caused substitution of the 588th amino acid [glutamine (Q) was replaced by histidine (p.Q588H)]. The c.1778 T>A transversion caused substitution of the 593th amino acid [isoleucine (I) was replaced by lysine (K) (p.I593K)] (Table 5).

\section{Discussion}

The Yili horse, which descends from the Kazakh horse reared by hybridization and crossed with Orlov Trotter, Don, Budyonny, and Akhalteke, is a breed both used for transportation and source of milk products (Yao et al., 2011). The dairy horse, New Kirghiz breed, was brought to China in 1991 to improve milk production of the Yili horse. Finding nucleotide variations linked to milk performance is important for cultivating dairy-type Yili horses. Several milk-production traits linked to PRLR polymorphisms have been identified in dairy cattle (Zhang et al., 2008; Lü et al., 2011). Thus, nucleotide mutation of the gene may also influence equine lactation performance. Reports on nucleotide mutations in the horse PRLR gene are not available, however.

The equine PRLR gene is located on chromosome 21. According to NW_001867391 and XM_001500104, it is approximately $14 \mathrm{~kb}$ in size and composed of 10 exons and 9 introns. Equine PRLR cDNA contains a 1878-nucleotide open reading frame (ORF) encoding the PRLR proprotein containing 625 amino acids. Interestingly, exons 1 and 2 are not translated. In this study, 12 pairs of primers were used to screen the nucleotide variations in the coding region of the horse PRLR gene, and 10 novel SNPs were found and identified. To the best of our knowledge, this paper is the first report on the polymorphisms found in the equine PRLR gene.

Six of the ten SNPs found in this study were synonymous mutations. The other four SNPs located in exon 10 of the PRLR gene caused amino acid substitutions (p.H409P, p.H427N, p.I593K, and p.Q588H). Exon 10 of the equine PRLR gene contains a $1023 \mathrm{bp}$ ORF and encodes part of the PRLR. Among the four substitutions, histidine and lysine are polar and basic amino acids; asparagine and glutamine are polar and neutral ones, while isoleucine is a non-polar neutral amino acid. Proline is a cyclic imino acid and is known to perturb the structure of the $\alpha$-helix in protein molecules by introducing a kink between the segments preceding and following the proline residue (Visiers et al., 2000). For p.H409P, when histidine is replaced by proline, the three-dimensional (3-D) structure of the PRLR would be affected. From a theoretical point of view, the other three substitutions would change the physical and chemical properties of PRLR molecules. The four-amino-acid substitutions are all found in the cytoplasmic domain of the PRLR, which plays a fundamental role in signal transduction. Thus, these substitutions may lead to functional changes on the PRLR.

In Chinese Holstein cows, two newly detected SNPs (g.9206G $>$ A and g.9681C $>$ T) within exon 10 of the $P R L R$ gene caused amino acid variations p.E378K and p.A536V, respectively. Statistical results indicate that the two SNPs were significantly associated with milk yields, and cows with the combined genotype GGCC showed superior milk performance (Lü et al., 2011). In another report, a c. $1645 \mathrm{G}>\mathrm{A}$ mutation within exon 10 of the dairy goat PRLR gene caused a p.V549M substitution and resulted in a variation in milk performance (Sun et al., 2008). Thus, the PRLR gene may affect milk 
traits in livestock, and exon 10 has an important role in the function of the PRLR gene. To date, the relationship between the PRLR genotypes and milk performance of horses has not been reported. Further experiments are needed to establish whether the four mutations found in this study affect milk performance of Yili horses.

Genetic parameters were calculated in this study. PIC value varied from 0.3318 to 0.1638 . According to the classification of PIC (high polymorphism if the PIC value is $>0.5$, median polymorphism with a PIC value of $0.25-0.5$, and low polymorphism with PIC values $<0.25$ ) (Han et al., 2011), the c. 156 $\mathrm{C}>\mathrm{T}$ and c. $312 \mathrm{~T}>\mathrm{C}$ showed median polymorphism, whereas the SNPs found within exon 10 of the horse PRLR gene showed low polymorphism.

\section{Conclusions}

In summary, nucleotide polymorphisms within eight exons of the equine $P R L R$ gene were screened using PCR-SSCP and DNA sequencing. Ten novel SNPs were identified, of which four, within exon 10 , were non-synonymous. Theoretically, the four nucleotide substitutions would result in an altered 3-D structure and functions of the PRLR molecules. Further study is required, however, to determine whether these mutations affect the milk yield of horses.

\section{Acknowledgment}

Special Fund for Agro-scientific Research in the Public Interest (201003075), the Major Scientific Projects of Xinjiang Uygur Autonomous Region (201130101) and the National Key Technology R\&D Program of the Ministry of Science and Technology of China (2012BAD45B02).

\section{References}

Bassam B.J., Caetano-Anolle's G., Gresshoff P.M., 1991. Fast and sensitive silver staining of DNA in polyacrylamide gels. Anal. Biochem. 196, 80-83

Berkowicz E.W., Magee D.A., Sikora K.M., Berry D.P., Howard D.J., Mullen M.P., Evans R.D., Spillane C., MacHugh D.E., 2011. Single nucleotide polymorphisms at the imprinted bovine insulin- like growth factor 2 (IGF2) locus are associated with dairy performance in Irish Holstein-Friesian cattle. J. Dairy Res. 78, 1-8

Brym P., Kaminski S., Wojcik E., 2005. Nucleotide sequence polymorphism within exon 4 of the bovine prolactin gene and its associations with milk performance traits. J. Appl. Genet. 45, 179-185

Hall T.A., 1999. BioEdit: A user-friendly biological sequence alignment editor and analysis program for Windows 95/98/NT. Nucl. Acids. Symp. Ser. 41, 95-98

Han B., Zhang H.L., Zeng L., Yang B., Abula R., Xu X.L. Chen Y., 2011. The Polymorphisms of $\beta_{2}$-adrenergic receptor gene on two cattle breeds in China. Asian J. Anim. Vet. Adv. 6, 715-722

Lü A., Hu X., Chen H., Jiang J., Zhang C., Xu H., Gao X., 2010. Single nucleotide polymorphisms in bovine PRL gene and their associations with milk production traits in Chinese Holsteins. Mol. Biol. Rep. 37, 547-551

Lü A., Hu X., Chen H., Dong Y., Zhang Y., Wang X., 2011. Novel SNPs of the bovine PRLR gene associated with milk production traits. Biochem. Genet. 49, 177-189

Maruya E., Saji H., Yokoyama S., 1996. PCR-LIS-SSCP (Low ionic strength single-stranded conformation polymorphism)--a simple method for high-resolution allele typing of HLA-DRB1, -DQB1, and -DPB1. Genome Res. 6, 51-57

Mullen M.P., Berry D.P., Howard D.J., Diskin M.G., Lynch C.O., Berkowicz E.W., Magee D.A., MacHugh D.E., Waters S.M., 2010. Associations between novel single nucleotide polymorphisms in the Bos taurus growth hormone gene and performance traits in Holstein-Friesian dairy cattle. J. Dairy Sci. 93, 5959-5969

Mullen M.P., Berry D.P., Howard D.J., Diskin M.G., Lynch C.O., Giblin L., Kenny D.A., Magee D.A., Meade K.G., Waters S.M., 2011. Single nucleotide polymorphisms in the insulin-like growth factor 1 (igf-1) gene are associated with performance in HolsteinFriesian dairy cattle. Front. Genet. 2, 3

Oto M., Miyake S., Yuasa Y., 1993. Optimization of nonradioisotopic single strand conformation polymorphism analysis with a conventional minislab gel electrophoresis apparatus. Anal. Biochem. 213, 19-22

Sambrook J., Russell D.W., 2001. Molecular Cloning:A Laboratory Manual.3rd Edn.,Cold Spring Harbor Laboratory Press, New York, ISBN:978087965774, pp., 1-99

Sun R.P, Wang L.X., Zhu G.Q., Wan G.G., Song Y.X., Liang Z.Y., Cao B.Y., 2008. Polymorphism of exon 10 of prolactin receptor gene and its relationship with milk performance of Xinong Saanen dairy goat. Acta Vet. Zootech. Sinica 39, 1654-1660

Visiers I., Braunheim B.B., Weinstein H., 2000. Prokink: a protocol for numerical evaluation of helix distortions by proline. Protein Eng. $13,603-606$

Yao X.K. 2011. Preliminery Study on chemical-physical indicators of mare's milk and lactation character of Yili horse, New Kirgiz horse and hybrid horse. Ph.D thesis, Xinjiang Agricultural University (China)

Zhang J.L., Zan L.S., Fang P., Zhang F., Shen G. Tian W.Q., 2008. Genetic variation of PRLR geneand association with milk performance traits in dairy cattle. Can. J. Anim. Sci. 88, 33-39 